\title{
Debatt
}

\section{Primär och sekundär diskurs om heder}

\section{Att problematisera givna föreställningar om förövare och brottsoffer i "hedersrelaterat våld och förtryck"}

Sedan nästan två decennier debatteras livligt det fenomen som går under beteckningen "hedersrelaterat våld och förtryck". I denna debattartikel argumenterar jag för att det finns två diskurser om heder, som jag i brist på bättre termer klassificerar som en primär respektive sekundär hedersdiskurs. Forskningsfältet liksom debatten om hedersrelaterat våld och förtryck är mycket polariserat och ideologiserat, något som jag anser har begränsat förståelsen av det komplexa fenomen som begreppet "hedersrelaterat våld och förtryck" försöker fånga.

Inom akademin, och även inom kulturjournalistiken, finns en tendens att göra diskursanalys av det offentliga samtal som utvecklats kring hedersbegreppet. Det är en vällovlig ansats, eftersom vårt språk styr hur vi uppfattar världen, och rasifierade stereotyper bör dekonstrueras. Samtalet om heder och dess språkbruk skapar rigida föreställningar om förövare och brottsoffer hos de Andra. Begrepp som "hedersrelaterat våld och förtryck" gör att vi identifierar en våldsproblematik bland invandrade familjer, som på många sätt framstår som skild från konflikter i etniskt svenska familjer (se exempelvis de los Reyes, 2003; Carbin, 2010; NCK, 2010; Wikström, 2012; Kriminalvården, 2015). I denna framställning framstår den unga invandrartjejen som det perfekta brottsoffret, kontrollerad och förtryckt av sin pappa, sina bröder och farbröder - ja, förmodligen av hela släkten. Hon lever under ett ständigt hot om våld, och allt hon vill är att leva ett fritt, "svenskt" liv, där hon själv styr över sin tid och sina aktiviteter, samt vem hon umgås eller har en relation med. Detta är det gängse narrativet, draget till sin spets (för exempel på denna offentliga diskurs om heder, se publikationer utgivna av Länsstyrelsen i Östergötland som sedan 2005 haft regeringens uppdrag att bedriva det förebyggande arbetet mot hedersrelaterat våld och förtryck på nationell nivå, se www.hedersfortryck.se). 
I en diskursanalys behöver man inte bry sig om huruvida det finns någon substans eller "verklighet" $\mathrm{i}$ det som diskursen beskriver. Snarare tvärtom, diskursen är ju ursprunget - det som skapar det vi ser i det verkliga livet, det vill säga den sociala praktik som blir konsekvensen av den sanningsregim som diskursen utgör. Men det kan bli förvirrande. Den svenska, offentliga diskursen som försöker att beskriva förtrycket och våldet kan ju i viss mån ses som sekundär, om vi accepterar att det finns en primär diskurs som faktiskt just skapar en specifik maktordning i starkt patriarkala miljöer. I denna primära diskurs skulle i så fall begrepp (på olika språk) som står för heder i värsta fall kunna legitimera våld och förtryck. En sådan diskurs skulle exempelvis kunna ha ett språkbruk som betecknar hur en man respektive en kvinna skall uppföra sig för att kunna åtnjuta respekt, och vilka sanktioner som måste vidtas om någon bryter mot hederskodexen för att hedern skall återupprättas.

Om jag tar mig rätten att generalisera, så anser jag att det faktiskt finns en tydlig patriarkal könsmaktordning i många familjer med invandrarbakgrund, men därmed inte sagt att inte liknande maktordningar kan finnas i andra sammanhang. För att förtydliga: jag anser att det utifrån etnografisk forskning inte råder något tvivel om att det finns en primär diskurs om heder i flera av de länder som människor emigrerat ifrån (se exempelvis klassiska studier som Peristiany, 1966; Bourdieu, 1979; Wikan, 1982, men även Socialstyrelsen, 1984; Koctürk-Runefors, 1991; Wikan, 2004; Mojab \& Abdo, 2004; Welchman \& Hossain, 2005; Onal, 2008 för att nämna några). Liknande traditionella föreställningar har existerat och existerar fortfarande i Sverige, men de har generellt sett under den sexuella frigörelsen från och med mitten av 1900-talet och framåt omförhandlats och därmed förändrats radikalt. Existensen av en primär hedersdiskurs förnekas ofta av de postkoloniala akademiker som vill avslöja den svenska, offentliga diskursen om heder - den jag ger beteckningen sekundär. Häri ligger en kontrovers som präglat den svenska forskningen, även om min terminologi förstås inte har använts (se Englund \& Larsson, 2004; Kurkiala, 2005; Ekström, 2009; Grutzky \& Åberg, 2013).

Jag skulle själv vilja reservera begreppet "hedersrelaterat våld och förtryck" för att stå för en viss typ av konsekvenser för barn och ungdomar som socialiseras in i traditionella könsroller. Detta våld ska inte likställas med partnervåld, som är ett våld som har likartade mekanismer överallt. Det finns ingen anledning att ha ett särskilt begrepp för partnervåld hos de Andra, och såtillvida instämmer jag med postkoloniala kritiker som menar att språkbruket kan användas för att förstärka en "vi-och-dom"-känsla. Men med min användning av begreppet "hedersrelaterat våld och förtryck" avser jag ett hot om våld som kan realiseras av familj och släkt gentemot barn, ungdomar och unga vuxna. Detta kan hända när den unge revolterar mot den traditionella, patriarkala synen på sexualmoral, könsroller och familjebildning. På så vis kan jag stämma in i den svenska diskurs som försöker beskriva problematiken, men menar att den diskursen på något sätt är sekundär - den fångar med sina begrepp endast de uppenbara konsekvenserna av den primära hedersdiskursens sociala praktik.

Den svenska offentliga diskursen har dock på flera viktiga punkter misslyckats med att 
beskriva det komplexa fenomen som hedersrelaterat våld och förtryck omfattar. Detta gäller framförallt den tudelade bilden av brottsoffer och förövare som framträder (se exempelvis Hanberger, Ghazinour \& Mårald, 2008, för en kritik av regeringens insatser). Det finns en tydlig föreställning av förövaren som den våldsbenägne och lättstötte invandrarmannen, vars heder går förlorad vid minsta lilla felsteg från sin dotters eller systers sida. Men är det verkligen så enkelt? Denna "förövare" kan också betraktas som ett offer. Han är på ett sätt ett offer för en struktur där han måste leva upp till föreställningar om en riktig man, som har kontroll på "sina" kvinnor i enlighet med den primära hedersdiskursen. Om vi accepterar existensen av en sådan primär diskurs, kan mannen också ses som ett offer för ett grupptryck och en mansroll som gör att mannen måste ta till våld för att få erkännande i sin grupp.

Den feministiska tolkningen av våld i nära relationer gör att vi gärna tänker i de enkla kategorierna manlig förövare och kvinnligt offer. Detta stämmer dock inte riktigt i det hedersrelaterade våldet: både män och kvinnor kan ses som både offer och förövare. Kvinnornas delaktighet i upprätthållandet av könsmaktsordningen och våldet, och till och med planering av hedersmord, är underskattad. Kvinnor betraktas endast som passiva brottsoffer; sällan som aktörer i sin egen rätt. Tyvärr är sanningen den att kvinnors heder också blir påverkade av att en kvinnlig släkting bryter mot hederskodexen, och på så sätt kan de bli motiverade att se till att hedern återupprättas i gruppen. Hedern bärs ju upp kollektivt, och för att rädda sin egen heder kan kvinnliga släktingar resonera som så att straffet bör verkställas för den felande kvinnan. Att kvinnor själva utgör en aktiv part i patriarkala strukturer, är förvisso inget nytt.

De män som är brottsoffer i det hedersrelaterade våldet glöms ofta bort, även om det finns viss forskning som exempelvis uppmärksammat homosexuella mäns utsatthet (Knutagård \& Nidsjö, 2004; Darj \& Nathorst-Böös, 2011). Den primära hedersdiskursen är extremt heteronormativ, och individer med annan sexuell identitet blir utsatta för ett svårt förtryck med hot om våld. Förutom att männen kan ses som offer som måste leva upp till en våldsam mansroll, kan de alltså liksom kvinnor själva vara brottsoffer. Unga män kan utsättas för hot, tvångsgifte och våld, utöver att många måste bära en stor ekonomisk börda för att leva upp till en traditionell idé om att det är männen som är försörjare för den utvidgade familjen. Med andra ord, män är också offer för de rigida könsroller som den primära hedersdiskursen tilldelar dem.

I ett gemensamt forskningsprojekt intervjuade doktoranden Hanna Cinthio klienter inom Kriminalvården, gärningspersoner vars brott kunde kopplas till heder (Ouis \& Cinthio, 2012). I detta sammanhang upptäckte vi en ny grupp brottsoffer: pojkvänner med samma etniska bakgrund som klienterna. Våldet verkar alltså inte alltid riktas mot den egna dottern eller systern eller släktingen, utan hennes pojkvän kunde lika gärna bli offer för våldet. Enligt klienterna/gärningspersonerna själva var detta särskilt motiverat när pojkvännen hade samma etniska och kulturella bakgrund som de själva, eftersom han 
borde ha vetat bättre och känt till deras koder när det gäller heder och sexualmoral. Provokationen blev således större än om pojkvännen hade haft etnisk svensk bakgrund, eftersom dessa unga män förväntades förstå vilka normer som gällde inom gruppen. Dessa brottsoffer har inte fått någon uppmärksamhet alls i den svenska sekundära diskursen om heder.

Istället finns det mycket stereotypiska föreställningar om det perfekta brottsoffret i den svenska hedersdiskursen. Offret i hedersrelaterad brottslighet är en stackars timid och förtryckt invandrartjej som inget hellre önskar än att ha sexuell frihet och kanske mest av allt en svensk pojkvän. Verklighetens brottsoffer är ofta aktiva och utåtagerande tjejer, som inte riktigt motsvarar den här bilden. De som revolterar öppet mot hedersnormerna, är de som blir hotade (se exempelvis unga tjejers berättelser i Björktomta, 2012).

I ett pågående forskningsprojekt tillsammans med professor Lotta Löfgren-Mårtenson undersöker vi hedersrelaterat våld och förtryck bland särskoleelever. Ett preliminärt resultat är att flickor med lindrig intellektuell funktionsnedsättning har en särskild utsatthet, eftersom de har svårt att tolka att de lever i "två kulturer" och de motsägelsefulla sexuella budskap som de möts av i dessa två. Dessa tjejer kan utsättas för bortgifte, men även hedersrelaterat våld från närstående i händelse av att de utmanar kulturella normer, utan att de kanske ens är helt medvetna om riskerna och konfliktområdena. Elever med en mer uttalad intellektuell funktionsnedsättning verkar lättare kunna acceptera sina föräldrars önskemål, och saknar delvis förmågan att protestera mot exempelvis ett bortgifte. Utsattheten är förvisso lika stor, men de verkar inte utmana normerna eller vara alltför utåtagerande i jämförelse med de som hade en lindrigare funktionsnedsättning. Därmed var barnen med större intellektuell funktionsnedsättning paradoxalt nog mer skyddade mot närståendes våld och vrede (Ouis \& Löfgren-Mårtenson, i manus).

Frågan om bortgifte av unga med intellektuell funktionsnedsättning är svår. Ur ett intersektionellt perspektiv skulle man kunna betrakta dessa brottsoffer som flerdubbelt förtryckta utifrån exempelvis kön, ålder, etnicitet, klass, sexualitet och funktionsnedsättning. Föräldrar som agerar för att gifta bort sina barn ses i den svenska diskursen endast som förövare, men drivkrafterna bakom agerandet är oftast en önskan om normalisering och att säkra omsorgsbehovet i framtiden. Vid bortgifte av unga med intellektuell funktionsnedsättning kan makan/ maken dessutom bli deras personliga assistent, vilket skulle kunna öka beroendeställningen och isoleringen ytterligare för den unge. Men de motiv som föräldrarna hänvisar till i detta fall handlar om moral, omsorg och gruppidentitet, det vill säga värden som inte brukar förknippas med brottslighet, utan med "det goda". Att gifta bort ett barn under 18 år är en kriminell handling i Sverige, men dessa föräldrar handlar med sina barns bästa för ögonen.

Hedersbegreppet ger konnotationer av stolta, lättkränkta män som förtrycker kvinnor. Det ligger nära till hands att associera problematiken till kriminella gäng med en uttalad hederskodex och där konsekvensen blir brutalt våld och övergrepp för den person som bryter mot normerna. Det är lätt att glömma bort att begreppet "heder" står för det som anses rätt och riktigt enligt de normer som råder i ett specifikt sammahang. I den sekundära 
hedersdiskursen betecknar heder framförallt våld i nära relationer och familjekonflikter, vilket blir lite motsägelsefullt eftersom heder står för positiva värden i den primära hedersdiskursen, såsom gästfrihet, pålitlighet och respekt för att nämna några. Dessa aspekter av hederskodexen försvinner helt i den svenska sekundära hedersdiskursen, som endast handlar om våld och förtryck.

Det glöms ofta bort att det ju inte bara är i "hederskulturer" som heder har en viktig funktion för att få människor att göra goda handlingar. Ett exempel som illustrerar hedern som det goda är inom akademin, där det finns mycket tydliga normer som definierar det som är hedersamt. Att bli ertappad med plagiat eller fusk skulle i ett akademiskt sammanhang innebära att en forskare eller student fullständigt förlorar sin heder. På så vis är det ju bra att det finns uppfattningar om heder som gör att vi utför de handlingar som anses goda, oavsett sammanhang.

Frånvaron av heder försätter människor i ett tillstånd av skam. Jag hade föredragit att vi i den svenska, sekundära diskursen istället hade använt oss av begreppet "skamrelaterat våld och förtryck", eftersom skam bättre förklarar de mekanismer som motiverar förövaren att ta till våld. Skam anses vara en av människans starkaste emotioner och innebär ett internaliserande av omgivningens fördömande. Skam står för själväckel och kräver åtgärder för att bli befriad ifrån. Skambegreppet förklarar bättre vad det är som driver förövare inom hedersrelaterad brottslighet, än vad hedersbegreppet gör. Att förstå vad skam gör med människor, kan skapa en begriplighet för föräldrars agerande. De är inte våldsamma föräldrar som vill sina barn illa, men de kan drivas av svåra skamkänslor som gör att de som sista åtgärd kan begå våldsbrott mot sina barn.

Forskningen om hedersrelaterat våld och förtryck är starkt ideologiserad i Sverige. Såväl forskare som debattörer verkar ha fastnat i att söka en enda förklaringsmodell till fenomenet. Feminister menar att våldet företrädesvis kan förstås utifrån kön och patriarkat (Lundgren, 2001; Nilsson \& Lövkrona, 2015). Antropologer, ibland misstolkade av främlingsfientliga krafter, pekar ut kulturella skillnader som förklaring till förtrycket och våldet (Wikan, 2004; Kurkiala, 2005). Andra lyfter fram marginalisering och strukturell rasism som en förklaringsmodell (Darvishpour, 2008), medan ytterligare andra menar att förståelse för våldet kan sökas på ett individuellt plan hos förövaren. Därutöver finns postkoloniala forskare som helt förnekar existensen av hedersrelaterat våld och förtryck, och som menar att det är en konstruktion för att misskreditera de Andra (se exempelvis de los Reyes, 2003; Englund \& Larsson, 2004, för detta perspektiv).

Själv hade jag föredragit att vi hade sökt en mångdimensionell förklaringsmodell till våldet, utifrån en intersektionell ansats där vi försöker förstå flera maktordningars samverkan utifrån olika sociala kategoriseringar. Självklart kan våldet förklaras utifrån kön, men det räcker inte som ensam förklaring. Vidare är kultur relevant för förståelsen, men att bara hänvisa till "deras kultur" är en grov förenkling. Samtidigt finns grupptryck och starka makthierarkier inom etniska, kulturella och religiösa föreningar som kan uppmuntra våldet 


\section{Socialvetenskaplig tidskrift 2015:3-4}

(Carlbom, 2003; Ouis, 2009, 2012). Vidare är strukturell rasism, exkludering och marginalisering viktiga pusselbitar för att förstå maktförskjutningar inom familjen. De enskilda familjemedlemmarna är både förövare och brottsoffer, och för att förstå deras drivkrafter måste vi även tillämpa individuella förklaringar som exempelvis berör skamkänslor, psykisk ohälsa eller missbruk. Allt detta spelar roll i det komplexa fenomen som hedersrelaterat våld och förtryck handlar om. Om vi går bortom våra egna fossilerade föreställningar och favoritförklaringar kanske vi kan skapa begriplighet för det obegripliga våldet; en djupare förståelse som innebär mer nyanserade och mångfacetterade bilder av såväl brottsoffer som förövare.

\section{Pernilla Ouis}

Docent i hälsa och samhälle inriktning etniska relationer

Institutionen för socialt arbete, Malmö Högskola

\section{Referenser}

Björktomta, Siv-Britt (2012) Om patriarkat, motstånd och uppbrott: Tjejers rörelser i sociala rum. Malmö: Egalité.

Bourdieu, Pierre (1979) Algeria 1960. The disenchantment of the world, The sense of honour, The Kabyle house or the world reversed. Cambridge: Cambridge University Press.

Carbin, Maria (2010) Mellan tystnad och tal. Flickor och hedersvåld i svensk offentlig politik. Stockholm: Stockholm studies in Politics 134.

Carlbom, Aje (2003) The Imagined versus the Real Other: Multiculturalism and the representation of Muslims in Sweden. Lund: Lund Monographs in Social Anthropology 12.

Darj, Frida \& Nathorst-Böös, Hedvig (2011) HBT \& heder: En intervjustudie om unga HBT-personer som lever ifamiljer med hedersnormer. Stockholm: Alma Europa \& RFSL Ungdom.

Darvishpour, Mehrdad (2008) Köns- och generationskonflikter inom invandrade familjer: Utifrån ett intersektionellt perspektiv. I: Darvishpour, Mehrdad \& Charles Westin (red.) Migration och etnicitet: Perspektiv på ett mångkulturellt Sverige. Lund: Studentlitteratur.

de los Reyes, Paulina (2003) Patriarkala enklaver eller ingenmansland? Vaild, hot och kontroll mot unga kvinnor i Sverige. Norrköping: Integrationsverket.

Ekström, Simon (2009) Hedersmorden och orden: Berättelser om kultur, kritik och skillnad. Göteborg: Makadam.

Englund, Cecilia \& Larsson, Stieg (red.) (2004) Debatten om hedersmord: Feminism eller rasism? Stockholm: Svartvitts förlag, Expo.

Grutzky, Eduardo \& Åberg, Lars (2013) Heder och samvete: En bok om hederskultur i Sverige. Stockholm: Fri Tanke.

Hanberger, Anders, Ghazinour, Mehdi \& Mårald, Gunilla (2008) Regeringens insatser mot hedersrelaterat våld 2003-2007 - slutrapport från den nationella utvärderingen. Evaluation Reports No 25. Umeå: Umeå Centre for Evaluation Research.

Knutagård, Hans \& Nidsjö, Elisabet (2004) Hedersrelaterat våld mot ungdomar på grund av sexuell läggning. Rapport 2004:24. Malmö: Länsstyrelsen i Skåne Län. 
Koctürk-Runefors, Tahire (1991) En fråga om heder: Turkiska kvinnor hemma och utomlands. Otta: Tidens förlag.

Kriminalvården (2015) Hedersrelaterat våld och förtryck: Forskning och utvärdering inom Kriminalvården. Norrköping: Kriminalvården.

Kurkiala, Mikael (2005) I varje trumslag jordens puls: Om vår tids rädsla för skillnader. Stockholm: Ordfront.

Lundgren, Eva, Heimer, Gun, Westerstrand, Jenny \& Kalliokoski, Anne-Marie (2001) Slagen dam: Mäns våld mot kvinnor i jämställda Sverige - en omfångsundersökning. Umeå: Fritzes Offentliga Publikationer.

Mojab, Shahrzad \& Abdo, Nahla (2004) Violence in the Name of Honour: Theoretical and Political Challenges. Istanbul: Istanbul Bilgi University Press.

NCK - Nationellt centrum för kvinnofrid (2010) Hedersrelaterat våld och förtryck - en kunskaps- och forskningsöversikt. NCK-rapport 2010:1 Uppsala: Nationellt centrum för kvinnofrid, Uppsala Universitet.

Nilsson, Gabriella \& Lövkrona, Inger (2015) Våldets kön: Kulturella föreställningar, funktioner och konsekvenser. Lund: Studentlitteratur.

Onal, Ayse (2008) Honour killing: Stories of Men Who KIlled. London: Saqi Books.

Ouis, Pernilla (2009) Barnen i Rosengård berättar vidunderliga och vedervärdiga saker. Praktik \& Teori, 1: 38-45.

Ouis, Pernilla (2012) Rör ved det urörlige. Social Kritik, 129: 93-96.

Ouis, Pernilla \& Cinthio, Hanna (2012) Slutrapport för projektet KV/U projektnummer 2010/151, projektkod 535660. Normkonflikter, relationer och kollektivt motiverat familjevåld (opublicerad rapport för Kriminalvården).

Ouis, Pernilla \& Löfgren-Mårtensson, Lotta. "Vi saknar strategier!" Om hedersrelaterat våld och förtryck bland unga med intellektuell funktionsnedsättning. I manus.

Peristiany, J. G. (red.) (1966) Honur and Shame: The Values of Mediterranean Society. Chicago: The University of Chicago Press.

Socialstyrelsen (1984) Heder och skam: Om sociala relationer i Medelhavsområdet. Socialstyrelsen redovisar 1984:2. Stockholm: Socialstyrelsen.

Welshman, Lynn \& Hossain, Sara (2005) 'Honour': Crimes, Paradigms, and Violence Against Women. London: Zed Books.

Wikan, Unni (1982) Behind the Veil in Arabia: Women in Oman. Chicago: The University of Chicago Press.

Wikan, Unni (2004) En fråga om heder. Stockholm: Ordfront förlag.

Wikström, Hanna (2012) Familj, heder och svenskhet. I: Marcus Herz (red.) Kritiskt socialt arbete. Malmö: Liber. 